\title{
Texts and Identities in the Early Middle Ages
}

Auxerre, Centre d'études médiévales, 17, 18 et 19 octobre 2008

\section{Régine Le Jan}

\section{CpenEdition}

Journals

\section{Édition électronique}

URL : https://journals.openedition.org/cem/7552

DOI : $10.4000 /$ cem.7552

ISSN : 1954-3093

Éditeur

Centre d'études médiévales Saint-Germain d'Auxerre

Édition imprimée

Date de publication : 15 août 2008

ISSN : 1623-5770

Référence électronique

Régine Le Jan, "Texts and Identities in the Early Middle Ages », Bulletin du centre d'études médiévales d'Auxerre / BUCEMA [En ligne], 12 | 2008, mis en ligne le 29 juillet 2008, consulté le 22 septembre 2022 URL : http://journals.openedition.org/cem/7552 ; DOI : https://doi.org/10.4000/cem.7552

Ce document a été généré automatiquement le 22 septembre 2022.

\section{(c) (1) (2)}

Creative Commons - Attribution - Pas d'Utilisation Commerciale - Partage dans les Mêmes Conditions 4.0 International - CC BY-NC-SA 4.0

https://creativecommons.org/licenses/by-nc-sa/4.0/ 


\title{
Texts and Identities in the Early Middle Ages
}

Auxerre, Centre d'études médiévales, 17, 18 et 19 octobre 2008

\author{
Régine Le Jan
}

1 Le groupe de recherches doctorales « Texts and Identities in the Early Middle Ages » se réunira au Centre d'études médiévales d'Auxerre du 17 au 19 octobre pour sa réunion annuelle. Le groupe a été constitué à l'initiative des professeurs Mayke de Jong (Utrecht), Régine Le Jan (Paris), Rosamond McKitterick (Cambridge), Walter Pohl (Vienne) et Ian Wood (Leeds), qui ont décidé de faire bénéficier leurs doctorants de leur expérience du travail en commun. Depuis douze ans, des doctorants venus des cinq centres se rencontrent autour du thème central de l'identité et présentent leurs recherches doctorales en cours à partir de l'étude des textes. Le croisement de méthodologies et de problématiques différentes et un dialogue très ouvert se sont révélés au fil des ans très fructueux. Les rencontres ont traditionnellement lieu à Cambridge, au Netherland Institute for Advanced Studies et à l'österreischiche Akademie der Wissenschaften de Vienne. L'équipe française s'est proposée pour organiser la rencontre de 2008 à Auxerre, afin de faire profiter les jeunes doctorants hauts médiévistes d'une infrastructure particulièrement bien adaptée à ce type de rencontres et d'un site médiéval exceptionnel, avec le musée et l'abbaye Saint-Germain en particulier.

2 Cette réunion rassemblera une trentaine de personnes. 